\title{
IMPLEMENTATION OF MARKETING IN MANAGERIAL FUNCTIONS OF BANKS
}

\author{
TOMAS-MISKIN Sonja ${ }^{1}$, VITOMIR Jelena \\ 1 Belgrade Banking Academy, UNION, Belgrade (SERBIA) \\ E-mail:sonjat984@gmail.com, jelena.vitomir1@gmail.com
}

\begin{abstract}
The marketing implementation as observed through the management in functioning of banks should be seen within the comprehensive management activities in order to achieve better defined business operations. The most common management can be observed through the internal management factors. The internal management control of a management of an enterprise is carried out with the primary goal of achieving much better business. Besides, management is in a constant search for a method by means of better controlling of the management of its trusted legal entity (banks). The aim of this paper is to point out the importance of implementation of marketing within the introduction of controls in banks. At the same time, the author draws attention that management should create conditions in which it will be enabled the process of controls to be regularly revised, that is approaching to the "optimal".
\end{abstract}

Key words: marketing, internal control of mechanisms, banks, optimization.

\section{JEL:M31}

UDC: 659.127.8:336.71

COBISS.SR-ID 277963532 


\section{INTRODUCTION}

Management seeks to establish control mechanisms that will increase the safety and security of business operations of an enterprise. Practically, it means that such mechanisms must be determined as following: establishing of internal control and internal audit, engaging of external audits and including other methods, with the aim of providing full support of management to attempting to increase the business safety. In addition, the established mechanisms of control contribute establishing of mechanisms of remunerations of employees.

The aim of the above-mentioned activities is to decrease the business risk. There is no generally accepted model of control implementation within an enterprise. Management along with the established control mechanisms implies a clear description of the roles and responsibilities when performing control starting from the positions of management, efficiency, implementation procedures within an enterprise, available resources provided to the responsible persons in charge of conducting controls.

Therefore, management provides adaptibility to the strategy of an enterprise and the protection of interests of the owner of an enterprise [1].

Foreign authors, especially those coming from the EU such as [2], emphasize the importance of introducing the internal control of mechanisms into the business operations of legal entities. A number of authors, such as [3], draw attention to the implementation of standardization, in particular the International Accounting Standards, by a large number of heterogeneous legal entities. The results published in those papers point out the importance of introducing the internal control of mechanisms in the regular business operation of legal entities, but also to the importance of full implementation of standardization in business.

It is of particular importance for reporting that is performed within banks that finance lending of of the economy, and they must take into account how to decrease the risks of funding the economy [2], [3].

\section{ESTABLISHING OF THE INTERNAL AUDIT IN THE CONTEXT OF INCREASING THE SAFETY OF MANAGEMENT}

Depending on the degree of programmed safety of the system, management determines to establish an internal audit, as a whole that will be supportive to the management function. The internal audit is attached to the work of the internal control. It should be emphasized that internal audit and internal control contribute to another control of business management, that is, they contribute to a more reliable work of external audit [4].

Internal control is incorporated into management activities of an enterprise. According to the author of the COSO (the Committee of Sponsoring Organizations), the internal control is inherent in the way how management runs the business [5].

Somewhat broader observation of the internal control involves observing the company policies, procedures, processes, plans, strategies, operations, systems, initiatives, activities, and other actions undertaken by the management in order to achieve the drfined business objectives [6]. The system of established internal control is an integral part of risk management and it is integrated into the management structure covering all areas of business operation of an enterprise [7]. 
It is important to emphasize that the system of internal control cannot provide complete safety in functioning of an enterprise [8].

Implementation of all forms of control in management represents a compromise between expenses and safety. Management should organize activities, plan and manage activities in order to achieve defined goals. [9].

The process of introducing the internal controls, represents a process that is designed by the highest managing bodies. Some authors consider that the supervisory board of an enterprise plays a dominant role, that is, management, with the aim of obtaining a reasonable assurance about the achievement of goals in the following areas:

- - improvement of the efficiency of decision-making by management,

- - increasing the reliability of financial reporting,

- preserving of the compatibility with applicable laws and regulations; and

- - protection of assets [10].

The International Accounting Standards and The International Financial Reporting Standards enable to management an optimal financial reporting [11], but it is also desirable to develop written clarification related to reporting [12] on the legal entity managed by management [13].

\section{SIGNIFICANCE OF DETERMINING THE INTERVAL RISK FOR THE MANAGERIAL FUNCTION OF THE MANAGEMENT}

In the context of observing the implementation of control mechanisms, one of the important positions for general management is to determine the risk interval. There are many methods for determining the risk. In this paper, it is given an overview of the potential impact of risk in relation to the type of activity (Table 1), as well as an overview made through the observation of the impact of the financial condition of legal entities (Table 2).

The impact of economic activity is presented in 9 categories, as well as the risk assessment in the interval 1-5, provided that 1 represen the minimum risk for business management.

Table 1. Impact of type of activity on risk assessment for management

\begin{tabular}{|c|l|c|}
\hline $\begin{array}{c}\text { Serial } \\
\text { number }\end{array}$ & \multicolumn{1}{c|}{$\begin{array}{c}\text { Name of the sector } \\
\text { / type of activity }\end{array}$} & Risk assessment \\
\hline 1 & Public sector enterprises & 1 \\
\hline 2 & Finance and insurance sector & 1 \\
\hline 3 & Processing industry & $\mathbf{2}$ \\
\hline 4 & Wholesaling and retailing & $\mathbf{2}$ \\
\hline 5 & Traffic & $\mathbf{2}$ \\
\hline 6 & Mining & $\mathbf{3}$ \\
\hline 7 & Agriculture and forestry & $\mathbf{3}$ \\
\hline 8 & Ltd in liquidation process & $\mathbf{3}$ \\
\hline 9 & Other & \\
\hline
\end{tabular}

Source: Author (2019) 
In Table 2 it is given an overview of some of the selected factors of an impact on financial condition with a risk assessment that is shown in the interval of 1-5, ptovided that the minimum risk according to management is validated with 1 .

Table 2. Overview of an impact of the selected factors on the evaluation of the financial condition

\begin{tabular}{|c|c|c|c|}
\hline $\begin{array}{l}\text { Serial } \\
\text { number }\end{array}$ & $\begin{array}{l}\text { Criteria for assessing } \\
\text { the financial status }\end{array}$ & $\begin{array}{l}\text { Observation } \\
\text { interval }\end{array}$ & Risk assessment \\
\hline \multirow[t]{3}{*}{1} & \multirow{3}{*}{$\begin{array}{l}\text { Number of insolvency } \\
\text { days in the last } 12 \\
\text { months }\end{array}$} & Up to 7 days & 1 \\
\hline & & From 8 to 30 days & 2 \\
\hline & & Over 30 days & 5 \\
\hline \multirow[t]{3}{*}{2} & \multirow{3}{*}{$\begin{array}{l}\text { Indicators of } \\
\text { indebtedness (ratio of } \\
\text { total loans and capital) }\end{array}$} & Less than or equal to 1 & 1 \\
\hline & & From 1 to 2 & 2 \\
\hline & & Over 2 & 5 \\
\hline \multirow[t]{3}{*}{3} & \multirow{3}{*}{$\begin{array}{l}\text { Profitability indicators } \\
\text { (ratio of net profit and } \\
\text { business income) }\end{array}$} & Above $8 \%$ & 1 \\
\hline & & Between 0 and $8 \%$ & 3 \\
\hline & & Incurred losses & 5 \\
\hline
\end{tabular}

Source: Author (2019)

\section{SOME OF THE IMPORTANT RISKS THAT THE BANK'S MANAGEMENT IS FACED WITH}

There are many risks that the bank's management structure is faced with in the business operation. In this paper, the author points out only some of them, such as:

1. Liquidity risk,

2. Loan risk that includes:

- Residual risk,

- Dilution risk,

- Settlement / delivery risk,

- The risk of the other contracting party.

3. Interest rate risk,

4. Market risks,

5. The Bank exposure risk, that is concentration risk,

6. The Bank investment risk,

7. Land risk,

8. Operational risk,

9. Compatibilty risk,

10. Reputational risk,

11. Strategic risk and

12. Risk of options. 
In order to show possible influence factors within the corporate responsibility of the banks, the author presents an overview of possible risks that banks are faced with in relation to time observation (short-term, medium-term and long-term), and the objective is to determine the risk interval, which has been defined by the author in the range from 1 to 5 , as a programmed possible risk interval.

Table 3. Overview of the model of determining the interval risk in relation to the length of time of the bank's impact

\begin{tabular}{|c|c|c|c|c|}
\hline \multirow{3}{*}{$\begin{array}{l}\text { Potential } \\
\text { corporate } \\
\text { impacts of the } \\
\text { bank }\end{array}$} & \multicolumn{3}{|c|}{$\begin{array}{c}\text { Impact of the Bank } \\
\text { from a temporal perspective }\end{array}$} & \multirow{3}{*}{$\begin{array}{l}\text { Numeric values } \\
\text { of risk } \\
\text { according to } \\
\text { corporate } \\
\text { positions of } \\
\text { impact of the } \\
\text { banks }\end{array}$} \\
\hline & short-term & medium-term & long-term & \\
\hline & \multicolumn{3}{|c|}{$\begin{array}{c}\text { Stated risk interval } \\
(1=\text { minimum; } 5 \text { = large risk interval })\end{array}$} & \\
\hline $\begin{array}{l}\text { Responsibility } \\
\text { towards clients } \\
\text { of the bank }\end{array}$ & $1-5$ & $1-5$ & $1-5$ & \\
\hline $\begin{array}{l}\text { Responsibility } \\
\text { towards } \\
\text { employees of the } \\
\text { bank }\end{array}$ & $1-5$ & $1-5$ & $1-5$ & \\
\hline $\begin{array}{l}\text { Responsibility } \\
\text { towards local } \\
\text { self-government }\end{array}$ & $1-5$ & $1-5$ & $1-5$ & \\
\hline $\begin{array}{l}\text { Responsibility to } \\
\text { the environment }\end{array}$ & $1-5$ & $1-5$ & $1-5$ & \\
\hline $\begin{array}{l}\text { Comprehensive } \\
\text { impacts on } \\
\text { ecology }\end{array}$ & $1-5$ & $1-5$ & $1-5$ & \\
\hline
\end{tabular}

Source (Author, 2019).

\section{IMPLEMENTATION OF MARKETING INTO THE MANAGEMENT OF LEGAL ENTITIES}

Legal entities invest money in marketing that promotes the main activities of an enterprise in fairs, sport events, global events and at other visible places that can be of promotional significance [14], [15], [16].

Marketing, modern communications, should also consider the factor of competitive advantage [17]. The consequences of socio-economic development, raising the living standard, increase in leisure time etc. change the image of a consumer in the world in the widest context [18], [19], [20]. 
The implementation of media events is performed continuously throughout the year, i.e. marketing promotion of an enterprise is carried out continuously [21].

The model of possible marketing of a real legal entity in the economy regarding marketing that is carried out by the author is shown in the graph 1 below.

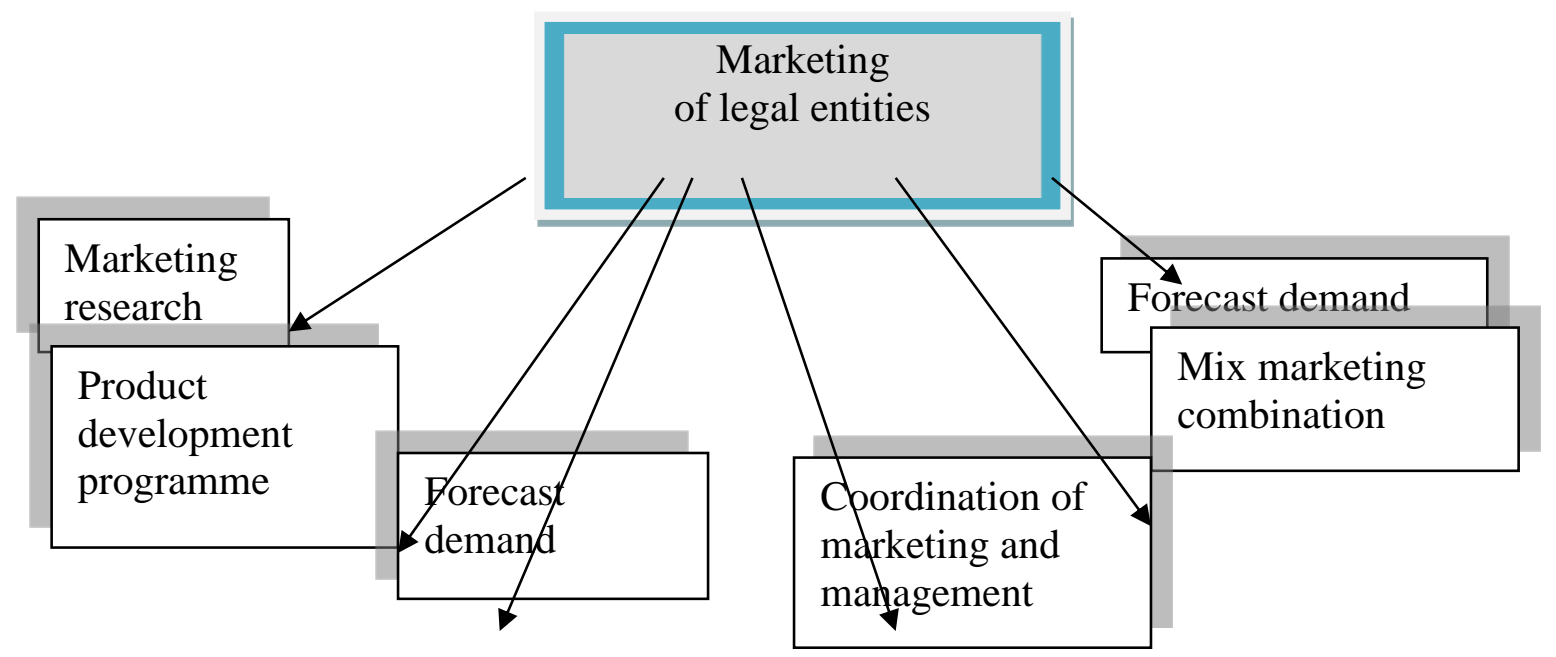

Graph 1: Model of possible marketing in legal entities

Source: Author (2019).

In its performance and business activities, top management should take into account market orientation by minimizing of all expenses, but with a certain degree of quality in making offers to potential clients, which is reflected in the economy of a large number of enterprises in the real economy which is dealing with several aspects by various authors [22], [23], [24].

The traditional marketing puts the focus of observation in:

- directing activities in favour of a specific event on the market,

- close observation of competition,

- understanding of visitors, i.e. understanding of a consumer as a rational participant, and

- implementation of analysis in realization of marketing of an enterprise.

Wider observation of marketing is directed towards four basic directions:

- experience of a consumer,

- procurement research,

- considering users as rational participants and

- implementation of modern and new methods in realization of marketing.

Based on an active approach to marketing, managers have been given the opportunity to have different approaches in combining marketing mix instruments. Therefore, the classification of the following types of marketing is noticed:

- designed marketing,

- sensitive marketing. 
- cognitive marketing, action marketing and

- bonding marketing that essentially combines the above-mentioned types of marketing into a single entity that any enterprise can adopt and implement in accordance with the given circumstances on the market.

It is important to emphasize that professionals who are in charge in implementing of marketing in enterprises in most cases use different marketing activities and they communicate with a large number of potential users and customers in the local and foreign market. Therefore, the marketing mix represents the combination of methods with the aim of achieving the proposed objectives. Decisions related to the marketing mix, in particular decisions on prices and promotion, are made in a shorter period of time, because they are subject to change. Marketing mix combinations show greater stability, since there are many combining posibilities.

Modern marketing that is applied by legal entities should consider: product, service, experience, event, personality, place, assets, organization, information and idea. The increase in income, the improvement of quality of life, changes in the lifestyle of urban people lead to the possibility of offering such products and services on the market.

Modern marketing is largely subject to changes that are conditioned by the implementation of information technologies.

The main goal of modern marketing that is applied by legal entities in the economy is to increase the exchange with consumers over a longer period of time, where loyalty between enterprises and consumers is created.

Thereby the common benefit from such a relationship can be observed in four principles:

- compiling a customer database,

- concept of access of an enterprise to the Internet,

- setting up a banner of an enterprise on related sites and

- enabling easy access and responding efficiently to customer calls.

\section{MARKETING CONNECTIONS OF THE ECONOMY AND BANKS}

The objective of these marketing activities is to increase profitability and to acquire and retain consumers. Electronic marketing refers to the implementation of marketing principles and methods through electronic media that is Internet. This allows enterprises to be informed, to advertise and to develop the sale of their products and services in a cheap and widely available manner.

It precisely represents the opportunity for digital marketing by respecting the concept of a sustainable consumer society at global, regional and local level.

The objective of economic activities is the implementation of modern marketing depending upon different market and technical and technological conditions, in order to increase the efficiency of business operation by the use of modern marketing.

The information age has imposed a new era and has changed the traditional distribution channels. The introduction of computer technology by manufacturer and by customer led to a decrease in expenses in many industries, and all of it must be filed, registered and processed by marketing in banks in order to offer to the economy an attractive banking product. 


\section{CONCLUSION}

Recently, in the Republic of Serbia, control mechanisms have been recognized and implemented to a significant extent in order to decrease the business risk. The first level of observation is the implementation of internal controls. The second level is the introduction of an internal audit that becomes an external audit support. The third level of implementation is the application and observation of control mechanisms within the public sector of the state. The fourth level of observation is the introduction of internal control mechanisms in other areas of the economy. In this paper, in relation to other areas of the economy, the analysis is mainly done through the observation of banks.

Another segment that is structurally presented in this paper is the significance of marketing implementation in banking institutions. The general conclusion arising from the paper is that management should establish control mechanisms in order to ensure work safety. Secondary conclusion points out to the importance of the implementation of marketing in banks. Banks should examine the behaviour of the economy as outlined in the paper and to provide appropriate responses in order to have interesting offers for legal entities. The last conclusion is incurred after the implementation overview of the use of marketing implementation and the introduction of new technological solutions, i.e. the conclusion is that we must use more methods aiming to promote new bank products and legal entities in general.

\section{REFERENCES}

[1] Popović S, Eremić-Đorđić J, Mijić R, (2014)-Interna kontrola u funkciji menadžmenta, Ekonomija - teorija i praksa br.2, Fimek, Novi Sad.

[2] Arena M, Arnaboldi M, Azzone G, (2006)-Internal audit in Italian Organizations: a Multiple Case Study, Managerial Auditing Journal, 21(3): 275-292.

[3] Barker R \& McGeachin A, (2013)-Why is there inconsistency in accounting for liabilities in IFRS? An analysis of recognition, measurement, estimation and conservatism, Accounting and Business Research. 43(6): 579-604.

[4] COSO, (1992)-Internal Control-Integrated Framework, Committee of Sponsoring Organizations, Jersey City.

[5] Vitorović B, (2002)-Uspostavljanje i organizovanje interne revizije, Revizor, broj 17, Institut za ekonomiku i finansije, Beograd.

[6] Chorafas D, (2001)- Implementing and Auditing the Internal Control System, Great Britain by Antony Rowe Ltd, Chippenham, Wiltshire.

[7] Stanišić M, (2006)-Modeli interne kontrole, Računovodstvo, br.9-10, Beograd.

[8] Soltani B, (2009)-Revizija, Međunarodni pristup, Mate, doo, Zagreb.

[9] Cantino V, (2009)- Korporativno uptravjanje, merenje performansi i normativna usaglašenost sistema internih kontrola, Data Status, Beograd.

[10] Flecher K, (2003)-Upravljanje marketingom i IT, Klio, Beograd.

[11] Fleming C, (2011)-Balancing Act - A major review is set to shake up standards setting in global financial reporting, Journal ICAEW, No 6.

[11]Popović S, Novaković S, Đuranović D, Mijić R, Grublješić Ž, Aničić J. \& Majstorović, A, (2017)-Application of international accounting standard-16 in a public company with predominantly agricultural activities, Economic Research-Ekonomska Istraživanja, 30: 1, $1850-1864$. 
[12] Vukasović D, (2010)-Računovodstvene informacije u službi korporativne decentralizacije, Svarog, No. 1: 181-188.

[13] Andrejević A, \& Grubor A, (2007)-Menadžment događaja, Novi Sad, Fakultet za uslužni biznis.

[14] Getz E, (1977)- ourism: Definition, Evolution and Research, Tourism management.

[15] Granados F. N, Kauffman J. R, Lai H, Lin H, (2011)-Decommoditization, Resonance Marketing and Information Technology: An Empirical Study of Air Travel Services amaid Channel Confilict, Journal of Managemenet Information Systems/Fall.

[16] Grgar D, Radanović B, (2013)-Digitalni marketing u funkciji razvoja preduzetništva, Poslovna ekonomija, Atelje Delač, Sr. Kamenica.

[17] Grubor A, (2013)-Marketing događaja, Anali, Ekonomski fakultet Subotica, Proleter a.d. Bečej.

[18] Hall C. M, (1997)-Hallmark Tourism Events: Impact, Management and Planning, John Willey.

[19] Kotler Ph, (2004)-The New Marketing Paradigm, PP prezentacija, Indiatimes Mindscape, Mumbai and Delhi.

[20] Kotler Ph, Wong V, Saunders J, Armstrong G, (2006)-Osnove marketinga, Mate, Zagreb.

[21] Terzić D, Popović V, Malić N, Ikanović J, Rajičić V, Popović S, Lončar M. \& Lončarević V, (2019)-Effects of long-term fertilization on yield of siderites and organic matter content of soil in the process of recultivation, The J. Anim. Plant Sci. 29(3).

[21] Bojović R, Popović V, Ikanović J, Živanović Lj, Rakaščan N, Popović S, Ugrenović V \& Simić D, (2019)-Morphological characterization of sweet sorghum genotypes acrossen vironments, The J. Anim. Plant Sci. 29(3).

[22] Radović M, Vitomir J, Laban B, Jovin S, Nastić S, Popović V. \& Popović S, (2019)Management of joint-stock companies and farms by using fair value of agricultural equipment in financial statements on the example of imt 533 tractor, Economics of Agriculture, 1: 35-50.

\section{Article history:}

- Received 1 April 2019

- Accepted 10 May 2019 